\title{
HUBUNGAN ANTARA STRES DAN MOTIVASI KERJA PADA MAHASISWA YANG BEKERJA PARUH WAKTU
}

\author{
Ni Wayan Sukmawati Puspitadewi \\ Program Studi Psikologi Universitas Negeri Surabaya \\ e-mail: cupid_kiky@yahoo.com
}

\begin{abstract}
The purpose of this study was to examine the relationship between stress and work motivation among students who have part-time jobs. The subjects of this study were 122 students whose ages ranged from 18 to 26 years old consisting of 68 men and 54 women from different universities in Surabaya and have part-time jobs for at least 6 (six) months in various fields. Sampling was conducted using quota sampling, while data collection is carried out by using a questionnaire. Data were analysed using Pearson's product moment. The results of data analysis shows that the correlation coefficient is -0.518 with $p=0.00(p<0.05)$ which means that there is a significant negative relationship between the level of stress and the level of work motivation among students who have part-time jobs. Thus, the lower the level of stress the students have the higher their work motivation and vice versa.
\end{abstract}

Key words: Stress, work motivation, students, part-timejobs

Abstrak: Penelitian ini adalah untuk mengetahui hubungan stres dengan motivasi bekerja pada mahasiswa yang bekerja paruh waktu. Subjek penelitian ini adalah 122 mahasiswa dengan rentang usia 18-26 tahun yang terdiri dari 68 laki-laki dan 54 perempuan yang berasal dari berbagai perguruan tinggi di Surabaya dan bekerja paruh waktu selama minimal 6 (enam) bulan dalam pelbagai bidang. Pengambilan sampel dilakukan dengan tekni quota sampling sedangkan pengumpulan data dilakukan dengan menggunakan angket. Data dianalisis secara statistik menggunakan metode Pearson correlation, yaitu product moment. Hasil analisis data menunjukkan koefisien korelasi sebesar -0,518 dengan $\mathrm{p}=0,00(\mathrm{p}<0,05)$ yang berarti bahwa ada hubungan negatif yang signifikan antara tingkat stres dengan tingkat motivasi bekerja pada mahasiswa yang bekerja paruh waktu. Makin rendah tingkat stres maka makin tinggi motivasi kerja seorang mahasiswa yang bekerja paruh waktu, begitu pula sebaliknya.

Kata kunci: Stres, motivasi kerja, mahasiswa, kerja paruh waktu

Manusia selalu mengadakan bermacam-macam aktivitas dalam kehidupannya, salah satunya diwujudkan dalam kegiatan yang dinamakan kerja. Bekerja mengandung arti melaksanakan suatu tugas yang diakhiri dengan buah karya yang dapat dinikmati oleh manusia yang bersangkutan. Aktivitas dalam kerja mengandung unsur kegiatan sosial, menghasilkan sesuatu dan pada akhirnya bertujuan untuk memenuhi kebutuhannya.

Mahasiswa sebagai penerus bangsa diharapkan mampu melalui kehidupan masa kini dan masa datang dengan baik, yaitu dengan belajar dengan giat dan memperoleh hasil yang maksimal dengan tepat waktu serta segera mendapatkan pekerjaan yang diinginkan dan hidup dengan layak. Mendapatkan pekerjaan yang baik merupakan harapan setiap mahasiswa, terutama mahasiswa yang baru saja lulus studinya. Semua akan terwujud bila-mana setiap mahasiswa berusaha sesuai dengan kemampuannya. Bagi seorang mahasiswa sangatlah penting bila didalam benaknya mempuanyai rencana untuk mengembangkan kemampuan dan keahliannya. Hal itu bisa menjadi dasar untuk mencari pekerjaan yang akan digelutinya.

Pada kenyataannya, seseorang mencari pekerjaan tidak mudah, karena membutuhkan berbagai macam keahlian dan pengalaman untuk mendapatkan pekerjaan yang layak. Atas dasar alasan itu pula, maka banyak 
mahasiswa yang mulai berpikir tentang masa depannya sehingga memutuskan untuk bekerja di sela-sela waktu kuliah.

Berdasarkan Badan Pusat Statistik Kota Surabaya tahun 2003, jumlah mahasiswa yang tersebar di PTS dan PTN di Surabaya sebanyak 28.236 orang. Sebuah survey dari Tim Deteksi Jawa Pos (2003:33) dari 1556 jumlah responden diketahui bahwa sebesar 65,4\% (1018 mahasiswa) menyatakan bahwa tidak pernah bekerja sambil kuliah, dan 34,6\% (538 mahasiswa) menyatakan bahwa pernah bekerja sambil kuliah. Terdapat 3 (tiga) bidang kerja tertinggi yang dijadikan pilihan pekerjaan paruh waktu mereka antara lain sebagai freelance (karyawan kontrakan), bekerja di bidang dagang, dan mengajar.

Jenis pekerjaan di perusahaan sangatlah beragam, terutama di bidang pemasaran produk dan jasa pelayanan. Sales Promotion Girl atau Sales Promotion Boy, model, pelayan toko, pelayan restorant, pelayan hotel, receptionist, les privat, penyiar radio, wartawan freelancer, event organizer dan sebagainya merupakan beberapa pekerjaan paruh waktu yang banyak di pilih mahasiswa. Mahasiswa atau anak muda, menurut Buhler (1962), senang dengan pekerjaan paruh waktu mungkin karena mereka menyukai gaya hidup yang lentur. Pada usia 24-44 tahun merupakan masa penentuan bagi diri individu termasuk dalam hal pekerjaan, sehingga mereka melakukan trial and error sebelum menetapkan akan tetap dalam pekerjaannya.

Kerja paruh waktu adalah pekerjaan secara teratur dan sukarela pada jam-jam yang pada dasarnya lebih pendek daripada jam kerja standar/baku (Sumber; Buku Glosarium Ketenagakerjaan Pusdatinaker). Berdasarkan UU No. 13 Tahun 2003 (Bab IX, pasal 56) tentang Ketenagakerjaan, jenis perjanjian (kontrak) kerja dapat dibagi 2 (dua) yatu : (1) perjanjian/ kontrak kerja waktu tertentu; (2) perjanjian/ kontrak kerja waktu tidak tertentu. Pekerjaan-pekerjaan yang telah disebutkan diatas termasuk dalam jenis perjanjian/ kontrak kerja waktu tertentu, karena dibuat untuk pekerjaan yang menurut jenis, sifat dan kegiatan pekerjaannya akan selesai dalam waktu tertentu.

Kuliah sambil bekerja belum umum diakukan di Indonesia, karena waktu efektif kuliah yang padat dan jenis pekerjaan yang ditawarkan secara paruh waktu tidak begitu banyak. Beberapa perusahaan di Indonesia, baik perusahaan besar maupun kecil memberikan kesempatan bekerja pada mahasiswa dengan beban kerja yang lebih ringan di banding karyawan biasa. Bekerja paruh waktu pada perusahaan besar, selain untuk mencari pengalaman, juga untuk menambah referensi mahasiswa dalam daftar riwayat hidup. Pekerjaan pada perusahaan tipe ini biasanya sudah terspesialisasi yang di dukung dengan prosedur kerja.

Motivasi mahasiswa untuk memilih bekerja paruh waktu disebabkan oleh banyak faktor. Menurut penelitian yang dilakukan oleh Dr. Claire Carney dari University of Glasgow pada tahun 2000, motivasi kerja pada mahasiswa bisa karena pemenuhan kebutuhan keuangan yang mendesak, atau sekedar mengisi waktu luang, ingin mendapatkan pengalaman bekerja, ingin bertemu dengan banyak orang (meningkatkan ketrampilan komunikasi), ingin meningkatkan ketrampilan dan keahlian dalam bekerja sehingga dapat meningkatkan karier di masa datang. Pengaruh faktor-faktor pendorong itu tampaknya berbeda kekuatannya antara mahasiswa yang satu dengan yang lainnya. Namun, menurut beberapa penelitian, faktorfaktor tersebut hampir seluruhnya memberikan pengaruh pada kebanyakan orang (Anoraga, 2001: 1-2). Kebanyakan dari mahasiswa yang memutuskan untuk bekerja paruh waktu, memilih tipe pekerjaan yang sangat beragam, mulai dari tipe pekerjaan yang paling melelahkan sampai ke tipe pekerjaan yang paling rileks, dari yang sederhana sampai modern.

Motivasi bekerja tidak hanya berwujud kebutuhan ekonomis saja (bentuk uang), tetapi juga dalam bentuk kebutuhan psikis 
untuk aktif berbuat yang terbaik bagi pekerjaan. Kuat lemahnya motivasi kerja seseorang ikut menentukan besar kecilnya prestasi (Wexley \& Yukl, 1977). Motivasi bersifat dinamik, dapat naik turun dengan cepat, dan manusia di dalam lingkungan pekerjaan tidak secara pasif menerima nasib dan kodratnya tapi juga dengan sadar berusaha untuk berprestasi dan mengaktualisasikan dirinya.

Setiap pekerjaan memiliki kesulitan, tantangan, ancaman dan beban kerja berbedabeda untuk memenuhi kebutuhan. Salah satunya adalah faktor kejenuhan dan ketegangan yang dapat menghinggapi siapa saja (termasuk juga mahasiswa) dan merupakan hal yang wajar. Kejenuhan dan ketegangan yang terjadi berlarut-larut dapat menimbulkan stres. Banyak hal dalam kehidupan ini yang dapat menyebabkan stres. Hal-hal yang menjadi sumber atau penyebab stres pada diri seseorang disebut stresor.

Proses pencapaian tujuan sering ada penghalang, kesukaran, dan kebimbangan yang menuntut seseorang untuk menyesuaikan diri yang dapat menimbulkan stres pada dirinya. Bila seseorang tidak dapat mengatasi segala halangan dan kendala tersebut dengan baik, maka akan muncul gangguan badan ataupun gangguan jiwa. Masalah penyesuaian diri atau keadaan stres dapat bersumber pada frustasi, konflik atau krisis (Maramis, 1990:65).

Sebuah hasil survey dari Student Affairs Universitas Buffalo (2005) menyatakan bahwa stres sering juga dialami oleh mahasiswa yang bekerja. Mereka kadang merasakan tekanan akademis, menyesuaikan diri dengan lingkungan baru, atau mengembangkan persahabatan dengan individu lain. Tekanan-tekanan yang bersifat pengalaman tidak terlalu membahayakan. Tekanan yang bersifat lunak dapat dijadikan sebagai motivator dan energizer. Bila tekanan yang terjadi pada mahasiswa terlalu tinggi maka dapat mengakibatkan permasalahan sosial dan kesehatan.
Beberapa jenis stres yang dialami oleh mahasiswa dibagi 4 (empat) kategori, yaitu : (1) perasaan (perasaan bersemangat, perasaan takut, emosi, dan sedih); (2) pemikiran (rendah diri, takut gagal, ketidakmampuan berkonsentrasi, cemas akan masa depan, dan sibuk dengan tugas-tugas); (3) perilaku (berbicara gagap, menangis, tertawa, merokok, menggunakan alcohol/narkotika, suka mencari tantangan/bahaya, dan banyak makan/hilang selera makan; (4) fisiologis (sering berkeringat, sering gelisah, detak jantung meningkat, mudah lelah, sering buang air kecil, sulit tidur, sakit kepala, sering muntah dan rentan terhadap penyakit). Stres yang berasal dari lingkungan antara lain adanya tekanan waktu, kompetisi, permasalahan keuangan dan rasa kecewa.

Berdasarkan uraian diatas maka dapat disimpulkan bahwa setiap orang yang bekerja pasti memiliki motivasi dalam mencapai tujuan yang ingin dicapai. Kadangkala dalam mencapai suatu tujuan selalu ada penghalang dan kesukaran yang menuntut seseorang untuk dapat menyesuaikan dirinya dengan stresor tersebut. Mahasiswa yang bekerja harus benar-benar dapat membagi waktu untuk kuliah dan bekerja, sebab tidak jarang mahasiswa mengalami berbagai macam gangguan yang berkaitan dengan kuliah dan pekerjaan. Konsentrasi terbelah, waktu yang terbatas dan terbagi, tuntutan tugas akademik, disiplin dalam bekerja, dituntut kinerja yang baik dalam pekerjaan dan lain-lain dapat menurun-kan motivasi.

Motivasi kerja yang menurun dapat mengakibatkan menurunnya prestasi kerja yang tentunya sangat merugikan diri mahasiswa dan perusahaan tempat ia bekerja. Demikian pula hal ini akan dialami oleh mahasiswa sendiri yang bekerja paruh waktu secara mandiri, seperti les privat, stres yang dialaminya dapat mempengaruhi motivasi kerjanya.

Stres dapat menghasilkan suatu akibat yang negatif, seperti mangkir bekerja, pekerjaan tidak selesai tepat waktu, performance 
kurang baik, dan sebagainya, melainkan juga dapat menghasilkan sesuatu yang positif, misalnya produktivitas meningkat dan performance baik. Individu dapat melakukan yang terbaik ketika terantang oleh suatu masalah, bukan ketika individu merasa bosan dan terpuruk. (William, 1997:16).

\section{METODE}

\section{Sampel}

Sampel penelitian adalah 122 mahasiswa berusia 18-26 tahun terdiri atas 86 lakilaki dan 54 perempuan, berasal dari perguruan tinggi di Surabaya yang masih aktif kuliah dan bekerja paruh waktu dipelbagai bidang pekerjaan dengan kurun waktu bekerja minimal 6 (enam) bulan. Waktu 6 (enam) bulan merupakan waktu yang cukup bagi mahasiswa untuk beradaptasi dengan lingkungan pekerjaannya dan mengenal tugas-tugasnya dengan baik.

Dalam penelitian ini teknik pengambilan sampel menggunakan non-random sampling, yaitu dimana tidak semua individu dalam populasi diberi kesempatan yang sama untuk manjadi anggota sampel (Hadi, 2004:89). Pemilihan non-random sampling karena peneliti tidak mengetahui secara pasti jumlah mahasiswa yang bekerja paruh waktu di Surabaya, sehingga ditetapkanlah ciri-ciri yang mewakili populasi yang telah ditetapkan. Jenis non-random sampling yang digunakan adalah quota sampling yaitu pengambilan sampel dengan sejumlah subyek yang akan diteliti ditetapkan terlebih dahulu (Hadi,2004:89), kemudian disebarkan angket siapa saja yang memenuhi kriteria dan bisa dihubungi.

\section{Teknikpengumpulan data}

Metode pengumpulan data yang digunakan dalam penelitian ini adalah metode angket langsung dan berstruktur. Angket langsung yaitu angket yang disampaikan secara langsung pada individu yang dimintai informasi tentang dirinya sendiri. Angket berstruktur berarti responden tinggal memberi tanda dan mengisi skala yang sudah di tentukan (Marzuki, 1983:65). Bentuk pertanyaan/pernyataan bersifat tertutup yaitu pertanyaan/pernyataan berbentuk kategoris (Kartono, 1986:207-208).

Angket dikonstruksikan berdasar model skala Likert, dimana seseorang diminta memberikan respon terhadap beberapa statement terdiri dari 2 (dua) kelompok item, yaitu item-item yang mendukung, (favorable), dan aitem-aitem yang tidak mendukung (unfavorable). Dalam penelitian ini alternative jawaban dalam skala Likert di modifikasi dengan penilaian antara lain, pernyataan favorable jawaban SS (sangat setuju) diberi nilai 4, jawaban S (setuju) diberi nilai 3, jawaban TS (tidak setuju) diberi nilai 2 dan jawaban SS (sangat tidak setuju) diberi nilai 1. Sedangkan untuk pernyataan unfavorable jawaban SS (sangat setuju) diberi nilai 1, jawaban $S$ (setuju) diberi nilai 2, jawaban TS (tidak setuju) diberi nilai 3, dan jawaban STS (sangat tidak setuju) diberi nilai 4. Dalam penelitian ini peneliti tidak mencantumkan jawaban netral karena jawaban netral memiliki arti ganda sehingga dapat diartikan belum dapat memutuskan atau memberikan jawaban atas suatu pernyataan. Penelitian ini menggunakan dua angket yaitu angket stres dan angket motivasi kerja. Kedua angket ini dikembangkan sendiri oleh peneliti dengan mengikuti langkah-langkah dalam pengembangan alat ukur psikologi (Suryabrata, 2005; Azwar, 2002).

\section{Teknik analisis data}

Data dianalisis secara statistik menggunakan teknik korelasi product moment dari Pearson untuk mengungkap hubungan antara stress dan motivasi kerja pada mahasiswa yang bekerja paruh waktu. 


\section{HASIL DAN PEMBAHASAN} Hasil

Dari hasil uji korelasi diperoleh nilai koefisien Pearson Product Moment untuk skor stres dan motivasi kerja sebesar $=-0,581$ dengan nilai $p=0,000(p<0,05)$ maka hipotesis nihil ditolak dan hipotesis alternatif diterima. Maka ada hubungan negatif yang signifikan antara variabel stres dengan variabel motivasi kerja pada taraf kepercayaan 0,05 . Dengan demikian dapat diartikan bahwa semakin tinggi stres maka semakin rendah motivasi kerja, begitu pula sebaliknya. Sumbangan efektif $\left(\mathrm{r}^{2} \times 100 \%\right)$ dari variabel stres terhadap motivasi kerja adalah sebesar $11,42 \%$, dengan demikian masih ada $88,58 \%$ variabel lain yang mempengaruhi motivasi kerja dan stres.

Berdasarkan hasil penelitian ini dapat disimpulkan bahwa hipotesis nihil (Ho) penelitian ini ditolak dan hipotesisi alternatif (Hi) penelitian ini diterima. Hal ini menunjukkan bahwa ada hubungan yang sangat signifikan antara stres terhadap motivasi kerja pada mahasiswa yang bekerja paruh waktu dengan koefisien korelasi (r) sebesar $-0,581 * *$ dengan nilai $\mathrm{p}=0,000$ pada taraf kepercayaan $(\alpha=0,05)$.

\section{Pembahasan}

William (1997:13) menyatakan bahwa sebenarnya banyak karyawan yang mengabaikan masalah stres yang mereka hadapi di tempat kerja, sehingga karyawan sendirilah yang dapat menentukan apakah akan menerima stres atau menolak stres itu sendiri. William (1997:15) juga menyatakan bahwa stres bisa membantu meningkatkan kinerja seorang karyawan agar dapat berkembang.

Stres dapat disebabkan oleh berbagai macam faktor baik internal maupun eksternal. Berdasarkan hasil penelitian ini, subyek penelitian memiliki tingkat stress yang cukup tinggi dan motivasi kerja yang tinggi. Hal ini diduga dapat disebabkan beberapa faktor, yaitu situasi kerja yang nyaman dan menye- nangkan, hubungan antar rekan kerja yang harmonis, hubungan antara karyawan dan atasan baik, atasan memperhatikan kebutuhan karyawannya, adanya rewards yang sesuai dengan pekerjaan, dan beban kerja yang tidak berat dapat mereduksi stress yang timbul. Individu tidak berlarut-larut dalam keadaan yang tertekan dan segera berusaha mencari solusi yang tepat. Kondisi tersebut sangat menguntungkan bagi individu dan perusahaan sehingga individu segera termotivasi kembali untuk meningkatkan performance kerja dalam perusahaan. Hasil penelitian selengkapnya dapat dilihat pada tabel dibawah ini.

Tabel 1. Distribusi Frekuensi Stres $(\mathrm{N}=122)$

\begin{tabular}{|c|c|c|c|}
\hline Kategori & Interval Nilai & Frekuensi & Prosentase (5) \\
\hline Sangat Tinggi & $\mathrm{X}>112,2$ & 0 & 0 \\
\hline Tinggi & $92,4,<\mathrm{X} \leq 112,2$ & 0 & 0 \\
\hline Cukup & $72,6<\mathrm{X} \leq 92,4$ & 87 & 71,31 \\
\hline Rendah & $52,8<\mathrm{X} \leq 72,6$ & 30 & 24,60 \\
\hline $\begin{array}{c}\text { Sangat } \\
\text { Rendah }\end{array}$ & $\mathrm{X} \leq 52,8$ & 5 & 4,10 \\
\hline Total & & 122 & 100 \\
\hline
\end{tabular}

Tabel 2 Distribusi Frekuensi Motivasi Kerja (N-122)

\begin{tabular}{|c|c|c|c|}
\hline Kategori & Interval Nilai & Frekuensi & Prosentase (5) \\
\hline Sangat Tinggi & $\mathrm{X}>112,2$ & 9 & 7,38 \\
\hline Tinggi & $92,4,<\mathrm{X} \leq 112,2$ & 63 & 51,64 \\
\hline Cukup & $72,6<\mathrm{X} \leq 92,4$ & 49 & 40,16 \\
\hline Rendah & $52,8<\mathrm{X} \leq 72,6$ & 1 & 0,82 \\
\hline Sangat Rendah & $\mathrm{X} \leq 52,8$ & 0 & 0 \\
\hline Total & & 122 & 100 \\
\hline
\end{tabular}

Dalam kondisi stres yang sedang, individu dapat mempertahankan keseimbangan hidup dan menghasilkan sesuatu yang memuaskan. Tentu saja tetap ada kemungkinan bahkan kadangkala individu merasa stres, namun stres tersebut tidak membuat individu cemas dan cepat kembali ke keadaan normal, sehingga pekerjaan dapat terselesaikan dengan baik.

Hal ini dapat dibuktikan dengan teori yang menyatakan hidup manusia tergantung pada kemampuan menghadapi bahaya secara tepat dan kuat. Tubuh kita menemukan cara untuk mengatasi stres. Stres bisa menjadi pemicu untuk memperkuat motivasi kerja karena fungsi-fungsi tubuh manusia pada saat normal tidak menyediakan energi atau sumber daya yang dibutuhkan untuk mengatasi 
ancaman fisik secara normal. Mekanisme untuk memperkuat daya kerja (fight response) mempersepsikan adanya suatu ancaman, sistem saraf manusia yang memicu perubahan -perubahan kimiawi yang kompleks di dalam tubuh manusia dan menyalurkan sumbersumber kekuatan menjadi suatu sentakan energi yang tiba-tiba dan menghasilkan kinerja puncak (William, 1997:17).

Namun pada kenyataannya, ada juga kondisi yang tidak menguntungkan seperti stres dapat menjadi motivator bagi seseorang untuk bekerja lebih baik. Stres bisa membantu individu meningkatkan kinerjanya dengan cara bereaksi dan menyesuaikan diri terhadap stres tersebut. (William,1997:14). Motivasi kerja individu makin meningkat bila banyak tekanan atau stres yang dihadapinya. Adanya niat yang kuat dari individu untuk mengendalikan dan melawan stres menjadi suatu kekuatan positif agar dapat menghasilkan sesuatu yang memuaskan.

Sebenarnya motivasi individu yang bekerja paruh waktu adalah untuk mengisi waktu luangnya selama liburan semester sambil mendapatkan pengalaman berharga yang berbeda sebelumnya selain juga karena faktor keuangan. Di samping itu jenis pekerjaan dan prosedur pelaksanaan pekerjaan yang fleksibel dan mudah diadaptasi dapat meningkatkan motivasi kerja seseorang apalagi bila disertai dengan rewards yang sesuai.

Hal ini sependapat dengan Rice (1999:5) yang menyatakan bahwa stres dapat mempertinggi kesadaran, meningkatkan kesiapsiagaan mental, dan sering juga menuju kearah cognitive superior dan pencapaian tingkah laku individu yang positif. Stres dapat membangkitkan motivasi seseorang untuk menciptakan suatu karya seni yang baik, yang secara teori ilmiah diperlukan oleh individu. Dengan kata lain, challenge-stress digunakan sebagai suatu sarana pertumbuhan dan perkembangan individu secara pribadi dan professional. Dibawah ini adalah hasil penelitian berdasarkan deskripsi tempat kerja.
Tabel 3. Deskripsi posisi/bagian di tempat kerjan $(\mathrm{N}=122)$

\begin{tabular}{|c|l|c|c|}
\hline No. & \multicolumn{1}{|c|}{ Bagian } & Jumlah & Prosentase (\%) \\
\hline 1 & Service care & 28 & 22,95 \\
\hline 2 & Surveryor & 17 & 13,93 \\
\hline 3 & Sales Promotion Boy/Girl & 9 & 7,38 \\
\hline 4 & Penulis & 9 & 7,38 \\
\hline 5 & Konselor & 8 & 6,56 \\
\hline 6 & Pemandu & 6 & 4,91 \\
\hline 7 & Design Grafis & 6 & 4,91 \\
\hline 8 & Kasir & 4 & 3,28 \\
\hline 9 & Bartender & 3 & 2,46 \\
\hline 10 & Mengajar & 3 & 2,46 \\
\hline 11 & Tele Marketing & 3 & 2,46 \\
\hline 12 & Editor & 2 & 1,64 \\
\hline 13 & Fasilitator & 2 & 1,64 \\
\hline 14 & Koordinator Penulis & 2 & 1,64 \\
\hline 15 & Kitchen & 2 & 1,64 \\
\hline 16 & Ekspedisi & 2 & 1,64 \\
\hline 17 & Fotografer & 2 & 1,64 \\
\hline 18 & Layout & 1 & 0,82 \\
\hline 19 & Administrasi & 1 & 0,82 \\
\hline 20 & Research \& Development & 1 & 0,82 \\
\hline 21 & Front Office & 1 & 0,82 \\
\hline 22 & IT Litbang & 1 & 0,82 \\
\hline 23 & Entry Data & 1 & 0,82 \\
\hline 24 & Pembuat kuisioner & 1 & 0,82 \\
\hline 25 & Reporter & 1 & 0,82 \\
\hline 26 & Supervisor Senior & 1 & 0,82 \\
\hline 27 & Skippy & 1 & 0,82 \\
\hline 28 & Ship EDC & 1 & 0,82 \\
\hline 29 & Broker & 1 & 0,82 \\
\hline 30 & Agen Asuransi & 1 & 0,82 \\
\hline 31 & Akuntan & 122 & 0,82 \\
\hline & Total & & \\
\hline & & 100 \\
\hline
\end{tabular}

Generasi muda di Indonesia sampai tahun 2003 mencapai 14.774 orang yang bekerja. Sebagaian besar atau sebanyak 9.165 otang yang bekerja adalah laki-laki (Sumber BPS, Sakernas 2003). Gambaran ini terlihat dari hasil penelitian bahwa sebagian besar subyek penelitian yang bekerja paruh waktu adalah laki-laki yaitu sebanyak 68 orang $(55,73 \%)$ dan yang berjenis kelamin perempuan sebanyak 54 orang $(44,26 \%)$. Berikut ini adalah hasil penelitian berdasarkan jenis kelamin subyek penelitian.

Tabel 4. Deskripsi Jenis Kelamin Subyek Penelitian (N=122)

\begin{tabular}{|c|c|c|}
\hline $\begin{array}{c}\text { Jenis } \\
\text { Kelamin }\end{array}$ & Jumlah & $\begin{array}{c}\text { Prosentase } \\
\text { (\%) }\end{array}$ \\
\hline Laki-laki & 68 & 55,73 \\
\hline Perempuan & 54 & 44,26 \\
\hline Total & 122 & 100 \\
\hline
\end{tabular}


Melihat prosentase antara jumlah lakilaki dan perempuan yang bekerja paruh waktu tidak jauh berbeda menandakan bahwa perempuan masa kini ingin mengekspresikan dirinya dengan memberikan kemampuan yang dimilikinya melalui bekerja. Perempuan berusaha untuk menyingkirkan marginalisasi dan subordinasi yang banyak terjadi pada masyarakat umum, di tempat kerja, rumahtangga, bahkan Negara (Fakih, 2000:14-15). Keinginan untuk mandiri secara financial, memiliki kemampuan untuk memimpin dan berada di posisi yang sejajar dengan laki-laki adalah harapan perempuan masa kini serta tetap tidak melupakan kodratnya sebagai seorang ibu dan istri dalam keluarga. Dibawah ini adalah hasil penelitian berdasarkan usia subyek penelitian.

Tabel 5. Deskripsi Usia Subyek Penelitian ( $\mathrm{N}=122)$

\begin{tabular}{|c|c|c|}
\hline Usia & Jumlah & Prosentase (\%) \\
\hline $24-26$ & 13 & 10,65 \\
\hline $21-23$ & 75 & 61,47 \\
\hline $18-20$ & 34 & 27,86 \\
\hline Total & 122 & 100 \\
\hline
\end{tabular}

Berdasarkan tabel 3.5 diatas terlihat bahwa sebagian subyek penelitian yang bekerja berusia 21-23 tahun sebanyak 75 orang $(61,47 \%)$. Kondisi tersebut terjadi karena diduga mahasiswa dengan usia 21-23 tahun adalah mahasiswa semester lima sampai semester tujuh. Pada semester itu jadwal kuliah sudah tidak terlalu padat lagi sehingga banyak waktu luang yang tersisa digunakan untuk bekerja paruh waktu serta mulai memasuki persiapan memasuki dunia kerja yang sesungguhnya.

Tabel 6. Frekuensi Tingkat Stres (Cukup) ditinjau dari Masa Kerja Subyek Penelitian (N=87)

\begin{tabular}{|c|c|c|}
\hline $\begin{array}{c}\text { Masa } \\
\text { Kerja(bulan) }\end{array}$ & Jumlah & Prosentase (\%) \\
\hline $49-60$ & 1 & 1,15 \\
\hline $37-48$ & 4 & 4,6 \\
\hline $25-36$ & 7 & 8,05 \\
\hline $13-24$ & 14 & 16,09 \\
\hline $6-12$ & 61 & 70,11 \\
\hline Total & 87 & 100 \\
\hline
\end{tabular}

Tabel 7. Frekuensi Motivasi Kerja Tinggi ditinjau dari Masa Kerja Subyek Penelitian $(\mathrm{N}=63)$

\begin{tabular}{|c|c|c|}
\hline $\begin{array}{c}\text { Masa } \\
\text { Kerja(bulan) }\end{array}$ & Jumlah & Prosentase (\%) \\
\hline $49-60$ & 0 & 0 \\
\hline $37-48$ & 3 & 4,76 \\
\hline $25-36$ & 5 & 7,94 \\
\hline $13-24$ & 10 & 15,87 \\
\hline $6-12$ & 45 & 71,43 \\
\hline Total & 63 & 100 \\
\hline
\end{tabular}

Berdasarkan tabel diatas dapat dilihat bahwa sebagian besar subyek penelitian yang mengalami stress cukup adalah subyek yang memiliki masa kerja 6-12 bulan sebesar $70,11 \%(\mathrm{~N}=61)$ dan motivasi kerja tinggi sebesar $71,43 \%(\mathrm{~N}=45)$. Hal ini dapat terjadi karena dimasa kerja 6-12 bulan individu mengalami berbagai tantangan dan pengalaman baru dalam pekerjaannya serta merupakan masa adaptasi individu dalam lingkungan pekerjaan. stress yag cukup dapat memotivasi individu untuk belajar dan berkarya lebih baik serta ingin menunjukkan bahwa dirinya mampu melaksanakan pekerjaan yang diberikan perusahaan dengan baik.

Tabel 8. Frekuensi Tingkat Stres (Cukup) ditinjau dari Jenis kelamin Subyek Penelitian (N=87)

\begin{tabular}{|c|c|c|}
\hline Jenis Kelamin & Jumlah & Prosentase (\%) \\
\hline Laki-laki & 50 & 57,47 \\
\hline Perempuan & 37 & 42,53 \\
\hline Total & 87 & 100 \\
\hline
\end{tabular}

Melihat data diatas, maka dapat disimpulkan bahwa laki-laki lebih banyak mengalami stres cukup sebanyak 50 orang $(57,47 \%)$ sedangkan perempuan sebanyak 37 orang $(42,53 \%)$. Hal ini sesuai dengan penelitian yang dilakukan Farber (1991) yang menyatakan bahwa laki-laki lebih rentan terhadap stres jika dibandingkan dengan perempuan. Banyak yang membandingkan jika wanita lebih lentur jika dibandingkan laki-laki karena perempuan dipersiapkan oleh masyarakat dengan lebih baik atau secara emosional lebih mampu untuk menangani tekanan yang lebih besar. Namun, ada beberapa variabel lain yang dapat mempengaruhi motivasi kerja pada mahasiswa yang bekerja 
paruh waktu selain stres, antara lain: kepribadian, locus of control, proses internalisasi, hubungan interpersonal, dan kepemimpinan.

Berkaitan dengan kepribadian, perbedaan kepribadian individu dapat menyebabkan sebagian mahasiswa relatif tidak mengalami penderitaan atau kerentanan terhadap stres dibanding karyawan lainnya. Sementara locus of control menentukan apakah seseorang mahasiswa memiliki kemampuan untuk mengontrol lingkungannya ataukah justru dikontrol oleh lingkungannya. Kontrol internal terjadi ketika mahasiswa sendirilah yang menentukan segala sesuatunya, baik dalam membuat keputusan, mengatur lingkungan kerjanya, atau bagaimana memanfaatkan tekanan untuk melakukan sesuatu. Kecenderungan stres meningkat ketika locus of control mahasiswa bersifat internal namun lingkungan pekerjaan terlalu membatasi keleluasaannya untuk berkreasi.

Pada proses internalisasi, konsep diri secara internal dapat memotivasi kerja mahasiswa. Mahasiswa merasa bahwa konsep diri yang ideal adalah diperoleh dan mengadopsi dari harapan dan peranan seseorang dalam kelompoknya. Dengan usaha mahasiswa untuk dapat bertindak sesuai dengan harapan dan peranannya dalam kelompok, maka ia akan mendapatkan umpan balik yang konsisten dengan persepsi dirinya. Sementara itu pada isu tentang hubungan interpersonal, mahasiswa akan terstimulasi ketika diberi suatu tanggungjawab yang mengimplikasikan adanya suatu otoritas untuk membuat perubahan atau mengambil keputusan. Mahasiswa yang diberi tanggungjawab dengan otoritas yang proporsional cenderung memiliki motivasi kerja yang tinggi. Meskipun demikian, cara kepemimpinan, terutama kepemimpinan demokratis, adalah faktor yang juga berperan penting dalam menciptakan kondisi yang kondusif bagi mahasiswa untuk bekerja dengan tenang dan harmonis dalam tim sehingga kecenderungan stres akan menurun dan, sebagai implikasinya, motivasi bekerja akan meningkat.

\section{SIMPULAN DAN SARAN}

Penelitian ini menyimpulkan bahwa ada hubungan yang signifikan antara stres dengan motivasi kerja pada mahasiswa yang bekerja paruh waktu. Namun, sumbangan efektif variabel stres terhadap motivasi kerja hanya sebesar $11,42 \%$, sehingga dapat disimpulkan bahwa selain stres ada faktor-faktor lain sebesar $88,58 \%$ yang mempengaruhi motivasi kerja pada mahasiswa yang bekerja paruh waktu. Faktor-faktor lain itu dapat diidentifikasi di antaranya adalah faktor kepribadian, locus of control, proses internalisasi, hubungan interpersonal, dan kepemimpinan. Saran yang dapat diberikan untuk peneliti selanjutnya adalah menguji bagaimana kelima faktor tersebut memberi pengaruh terhadap stres khususnya pada mahasiswa yang bekerja paruh waktu.

\section{DAFTAR PUSTAKA}

Anoraga, P. (2001). Psikologi Kerja, Cetakan keIII, Jakarta: Penerbit Rineka Cipta.

Azwar, S. (2002). Tes Prestasi, Cetakan Ke-V, Yogyakarta : Penerbit Pustaka Pelajar.

Azwar, S. (2005). Penyusunan Skala Psikologi, Yogyakarta : Penerbit Pustaka Pelajar.
Fakih, M. (2000). Mengeser Konsepsi Gender dan Transformasi Sosial, Bandung : Penerbit Pustaka Belajar.

Hadi, S. (2004). Metodologi Research Edisi 1, Yogyakarta : Penerbit Yayasan Penerbitan Fakultas Psikologi Universitas Gadjah Mada. 
Kartono, K. (2002). Psikologi Sosial Untuk Manajemen Perusahaan dan Industri, Jakarta : Penerbit PT.Raja Grafindo Persada.

Maramis, W.F. (1990). Catatan Ilmu Kedokteran Jiwa, Surabaya : Airlangga University Press.

Rice, P.L. (1999). Stres and Health (3th Ed), California : An International Thomson Publishing Company.

Student Affairs University at Buffalo. (2005). Stress Management. Http://UbCounseling.Buffalo.Edu/Stressmanageme nt.Shtml. Diakses pada tanggal 6 Juli 2005.
Suryabrata, S. (2005). Metodologi Penelitian, Jakarta : Penerbit CV. Rajawali.

Jawa Pos. (14 Agustus, 2003). Uang Bukan Yang Utama Pandangan untuk Mahasiswa yang Bekerja. Rubrik Deteksi, hlm.33.

Wexley, K.N. and Yuk1, G.A. (1997). Reading in Organizational and Industrial Psychology, New York: Oxford Universitty Press. 